\title{
PENGARUH LATIHAN RANGE OF MOTION TERHADAP KEKUATAN OTOT PADA LANSIA DENGAN STROKE
}

\author{
Astri Pradesti ${ }^{1}$ \\ DIII Keperawatan, Politeknik Yakpermas Banyumas \\ Email astripradesti15@gmail.com \\ Puji Indriyani ${ }^{2}$ \\ DIII Keperawatan, Politeknik Yakpermas Banyumas \\ Email pj.indriyani@gmail.com
}

\begin{abstract}
ABSTRAK
Stroke merupakan salah satu masalah kesehatan yang cukup serius dalam kehidupan modern saat ini. Menuru World Health Organization (WHO) menjelaskan bahwa stroke merupakan penyebab kematian utama secara global. Diperkirakan 17.7 juta orang meninggal karena stroke pada tahun 2015 mewakili 31\% dari semua kematian global. Penelitian ini bertujuan untuk mengetahui Pengaruh Latihan Range Of Motion (Rom) Pasif Terhadap Peningkatkan Kekuatan Otot Pada Pasien Stroke Non Hemoragik. Metode penelitian ini menggunakan metode Literatur Riview antara jurnal satu dengan jurnal lainnya. Hasil penelitian diketahui bahwa kekuatan otot ekstremitas atas pada pasien stroke non hemoragik sebelum dilakukan latihan Range Of Motion (ROM) pasif memiliki tingkat kekuatan otot yang sangat kecil, kekuatan otot ekstremitas atas pada pasien stroke non hemoragik sesudah dilakukan latihan Range Of Motion (ROM) pasif, terjadi perbaikan atau peningkatan. Adanya pengaruh yang signifikan antara sebelum dilakukan latihan Range of Motion (ROM) pasif, terjadi perbaikan atau peningkatan dan adanya pengaruh yang signifikan antara sebelum dilakukan latihan Range Of Motion (ROM) pasif dan setelah tujuh hari pemberian latihan Range Of Motion (ROM) pasif.
\end{abstract}

Kata Kunci: stroke, kekuatan otot, ROM

\section{ABSTRACT}

Stroke is one of the most serious health problems in modern life today. The World Health Organization (WHO) explains that stroke is the leading cause of death globally. An estimated 17.7 million people died of stroke in 2015 representing 31\% of all global deaths. This study aims to determine the Effect of Passive Range Of Motion (Rom) Exercise on Improving Muscle Strength In Non-Hemorrhagic Stroke Patients. This research method uses the Riview Literature method between one journal and another. The results found that upper extremity muscle strength in non-hemorrhagic stroke patients prior to passive Range Of Motion (ROM) exercises had very small levels of muscle strength, upper extremity muscle strength in non-hemorrhagic stroke patients after passive Range Of Motion (ROM) exercises, improvements or enhancements occurred. There is a significant influence between prior passive Range of Motion (ROM) exercises, improvements or improvements and significant influences between before passive Range Of Motion (ROM) exercises and after seven days of passive Range Of Motion (ROM) exercises.

Keywords: stroke, muscle strength, ROM

\section{PENDAHULUAN}

Stroke adalah penyakit neurologis terbanyak yang dapat mengakibatkan masalah kesehatan yang serius dan berdampak pada kecacatan, kematian, dan ekonomi keluarga, akibat dari adanya disfungsi motorik dan sensorik (Subianto,
2012) Pasien dengan stroke akan mengalami gangguan-gangguan yang bersifat fungsional. Gangguan sensoris dan motorik post stroke mengakibatkan gangguan keseimbangan termasuk kelemahan otot, penurunan fleksibilitas jaringan lunak, serta gangguan kontrol 
motorik dan sensorik. Fungsi yang hilang akibat gangguan kontrol motorik pada pasien stroke mengakibatkan hilangnya koordinasi, hilangnya kemampuan keseimbangan tubuh dan postur (kemampuan untuk mempertahankan posisi tertentu) (Irfan, 2010 Santoso \& Ali, 2013).

Salah satu dampak yang terjadi pada pasien stroke adalah mengalami kelemahan di salah satu sisi tubuh yang terpengaruh stroke. Kelemahan ini bisa menimbulkan ketidak seimbangan dan kesulitan pada saat berjalan karena gangguan pada kekuatan otot, keseimbangan dan koordinasi gerak (Irdawati, 2008 dalam Sukmaningrum 2012).

Latihan ROM merupakan salah satu bentuk latihan dalam proses rehabilitasi yang dinilai cukup berpengaruh untuk mencegah terjadinya kecacatan pada penderita stroke. Latihan ini adalah salah satu bentuk intervensi fundamental perawat yang dapat dilakukan untuk keberhasilan regimen terapeutik bagi penderita dan dalam upaya pencegahan terjadinya kondisi cacat permanen pada penderita stroke paska perawatan di rumah sakit, sehingga dapat menurunkan tingkat ketergantungan penderita pada keluarga, meningkatkan harga diri dan mekanis mekoping penderita. Lewis (2010) mengemukakan bahwa sebaiknya latihan pada penderita stroke dilakukan 2 kali dalam sehari untuk mencegah komplikasi, semakin dini proses rehabilitasi di mulai, maka kemungkinan penderita mengalami defisit kemampuan akan semakin kecil. Penelitian menunjukan bahwa latihan ROM dapat meningkatkan fleksibilitas dan rentang gerak sendi. Latihan ROM dilakukan selama 1 minggu dan 2 minggu, 1 hari 2 kali yaitu pagi dan sore selama 10-15 menit, maka memiliki kesempatan untuk mengalami penyembuhan dengan baik (Murtaqib, 2013).

Berdasarkan uraian latar belakang di atas maka peneliti tertarik untuk melakukan penelitian tentang "Latihan Range of Motion (ROM) Terhadap Kekuatan otot pada Lansia dengan Stroke"

\section{METODE PENELITIAN}

Metode penelitian yang digunakan dalam penelitian ini adalah metode deskriptif, yaitu suatu metode dalam meneliti status sekelompok manusia, suatu objek, suatu set kondisi, suatu sistem pemikiran ataupun suatu kelas peristiwa pada masa sekarang. Dengan tujuan untuk membuat deskripsi, gambaran atau lukisan secara sistematis, faktual dan akurat mengenai fakta-fakta, sifat- sifat serta hubungan antar fenomena yang diselidiki (Nazir, 2017)

Jenis penulisan yang digunakan adalah studi literatur review yang berfokus pada hasil penulisan yang berkaitan dengan topik atau variable penulisan. Studi literatur bisa didapat dari berbagai sumber baik jurnal, buku, dokumentasi, internet dan pustaka. Metode studi literatur adalah serangkaian kegiatan yang berkenaan dengan metode pengumpulan data pustaka, membaca dan mencatat, serta mengelolah bahan penulisan (Nursalam, 2013). Penelitian ini peneliti melakukan penelitian tentang pengaruh range of motion (ROM) terhadap kekuatan otot pada lansia dengan stroke.

\section{HASIL DAN PEMBAHASAN}

Dari hasil observasi terhadap responden 
dengan pengaruh latihan (ROM) pasif terhadap kekuatan otot ekstremitas pada pasien stroke di Ruang RA4 RSUP $\mathrm{H}$. Adam Malik Medan Tahun 2014 berdasarkan jenis kelamin sebanyak 8 responden (67) laki-laki, 4 responden (33\%) perempuan. Berdasarkan usia responden dengan usia 45-65 tahun sebanyak 6 responden (50\%) sedangkan responden dengan usia 65 tahun masingmasing sebanyak 3 responden (25\%), dan usia 45-65 tahun 6 responden (50\%). Berdasrkan pekerjaan, responden bekerja sebagai IRT sebanyak 4 responden (33\%), buruh/petani 1 responden (8\%), wiraswasta 5 responden (42\%) dan PNS 2 responden (17\%). Berdasarkan suku responden dengan suku Aceh sebanyak 2 responden (17\%), suku Batak 5 responden (41\%), suku Jawa 2 responden (16\%) dan suku Karo 3 responden (25\%). Berdasarkan frekuensi serangan responden dengan serangan pertama sebanyak 8 responden $(66 \%)$, serangan kedua 4 responden (34\%). Berdasarkan lama perawatan responden dengan lama perawatan 2 minggu sebanyak 8 responden (66\%), 3 minggu 4 responden (33\%). Berdasarkan tingkat kekuatan otot sebelum dilakukan latihan Range of Motion (ROM) pasif, responden dengan tingkat kekuatan otot 1 sebanyak 8 responden (67\%) dan tingkat kekuatan otot 2 sebanyak 4 responden (33\%). Berdasarkan tingkat kekuatan otot sesudah dilakukan latihan Range of Motion (ROM) pasif, responden dengan tingkat kekuatan otot 1 sebanyak 2 responden (17\%), tingkat kekuatan otot 2 sebanyak 3 responden $(25 \%)$ dan tingkat kekuatan otot 3 sebanyak 7 responden (58\%). Hasil pengukurun responden berdasarkan tingkat kekuatan otot ekstremitas atas pada responden 1,3,9 sebelum dilakukan latihan Range Of Motion (ROM) Pasif tingkat kekuatan ototnya masing-masing nilai 1 sesudah dilakukan latihan masingmasing meningkat menjadi nilai 3. Pada responden 2,7,12 sebelum dilakukan latihan Range Of Motion (ROM) Pasif tingkat kekuatan ototnya masingmasing nilai 1 sesudah dilakukan latihan masingmasing meningkat menjadi nilai 2. Pada responden 4,6,8,10 sebelum dilakukan latihan Range Of Motion (ROM) Pasif tingkat kekuatan ototnya masing-masing nilai 2 sesudah dilakukan latihan masingmasing meningkat menjadi nilai 3 . Sedangkan responden 5 dan 11 sebelum dan sesudah dilakukan latihan Range Of Motion (ROM) Pasif nilainya masih tetap 1, tidak mengalami peningkatan. 2. Bivariat Dari hasil penelitian, sebelum dilakukan Range Of Motion (ROM) pasif pada pasien stroke non hemoragik, kekuatan otot ekstremitas atas responden menunjukkan nilai kekuatan otot yang kecil dengan nilai 1-2. Namun setelah dilakukan latihan Range Of Motion (ROM) pasif pada seluruh responden, terjadi peningkatan kekuatan otot ekstremitas atas yang didominasi dengan nilai kekuatan otot 3. Pembahasan Dari hasil penelitian ini peneliti menemukan bahwa $\rho=0,068$, berarti Ho ditolak dan Ha diterima, yang artinya ada pengaruh latihan Range Of Motion (ROM) pasif terhadap peningkatan kekuatan otot ekstremitas atas pada pasien stroke non hemoragik. Hasil penelitian ini sesuai dengan Astrid (2011), yang menyatakan ada pengaruh latihan Range Of Motion (ROM) pasif terhadap peningkatan kekuatan otot. Selain itu, karakteristik demografi responden sangat mempengaruhi peningkatan kekuatan otot. Kekuatan otot sebelum dilakukan latihan Range Of Motion (ROM) pasif pada usia 45-65 tahun sebesar 50\% hal ini disebabkan karena penurunan aktivitas yang dapat menyebabkan timbulnya kelemahan otot serta atrofi. Dan terjadi 
peningkatan otot setelah dilakukan latihan Range Of Motion (ROM) pasif kekuatan otot 2 menjadi kekuatan otot 3. Dan pada usia

\section{Tabel, Grafik, Gambar dan/atau Foto}

Tabel, grafik, gambar, dan/atau foto (jika ada) diberi nomor, judul, dan keterangan lengkap serta dikutip dalam teks. Tabel, grafik, gambar, dan/atau foto diberi nomor sesuai dengan urutan kemunculannya. Tabel dan gambar harus jelas terbaca dan dapat dicetak dengan baik karena jika naskah akan dicetak, ia akan muncul dalam format warna hitam putih. Pencantuman tabel/data yang terlalu panjang (lebih dari satu halaman) sebaiknya dihindari. Perujukan, pengutipan, atau pencantuman gambar, tabel, dan sebagainya menggunakan penomoran, bukan dengan kata-kata "sebagai berikut", "seperti di bawah ini", dan sebagainya. Gambar, tabel, grafik, foto harus diletakkan sedekat mungkin dengan teks yang berhubungan. Tabel hanya menggunakan garis horisontal dan tanpa garis vertikal.. Setiap kolom tabel harus diberi tajuk/heading. Contoh:

Tabel 1

\section{Literature Jurnal}

\begin{tabular}{|c|c|c|c|}
\hline No & Judul & Pengarang & Tahun \\
\hline 1. & $\begin{array}{l}\text { Pengaruh } \\
\text { latihan } \\
\text { (rom) pasif } \\
\text { terhadap } \\
\text { kekuatan } \\
\text { otot } \\
\text { ekstremitas } \\
\text { pada pasien } \\
\text { stroke }\end{array}$ & $\begin{array}{l}\text { Zainuddin } \\
\text { Harahap }\end{array}$ & 2014 \\
\hline 2. & $\begin{array}{l}\text { Pengaruh } \\
\text { Latihan } \\
\text { Range Of }\end{array}$ & $\begin{array}{l}\text { Endah Sri } \\
\text { Rahayu1, } \\
\text { Nuraini }\end{array}$ & 2019 \\
\hline
\end{tabular}
Motion
(ROM)
Pasif
Terhadap
Peningkatan
Kekuatan
Otot Pada
Pasien
Lansia
dengan
Stroke Non
Hemoragik

\section{SIMPULAN}

Dari hasil penelitian ini dapat disimpulkan bahwa kekuatan otot ekstremitas atas pada pasien stroke non hemoragik sebelum dilakukan latihan Range Of Motion (ROM) pasif memiliki tingkat kekuatan otot yang sangat kecil. Kekuatan otot ekstremitas atas pada pasien stroke non hemoragik sesudah dilakukan latihan Range Of Motion (ROM) pasif, terjadi perbaikan atau peningkatan. Adanya pengaruh yang signifikan antara sebelum dilakukan latihan Range of Motion (ROM) pasif, terjadi perbaikan atau peningkatan. Adanya pengaruh yang signifikan antara sebelum dilakukan latihan Range Of Motion (ROM) pasif dan setelah tujuh hari pemberian latihan Range Of Motion (ROM).

\section{SARAN}

Disarankan bagi perawat untuk memberikan latihan Range Of Motion (ROM) pasif kepada pasien stroke yang mengalami kelemahan otot secara teratur dalam bentuk latihan dua kali sehari selama 15-30 menit dengan pengulangan empat kali setiap gerakan. Karena terbukti berpengaruh terhadap peningkatan kekuatan otot pasien. Kepada Instalansi Rumah Sakit perlu memasukkan latihan Range Of Motion (ROM) pasif kedalam 
prosedur tetap dalam perawatan pasien stroke, karena latihan Range Of Motion (ROM) pasif. Terbukti meningkatkan kekuatan otot pasien. Dan bagi peneliti selanjutnya diharapkan waktu pemberian latihan lebih lama minimal 4 minggu. Setelah itu, perlu diidentifikasi faktorfaktor apa saja yang mempengaruhi kekuatan otot pasien stroke.

\section{UCAPAN TERIMA KASIH}

Puji syukur saya panjatkan kepada Tuhan Yang Maha Esa, karena atas berkat dan rahmat-Nya, saya dapat menyelesaikan tugas akhir ini. Tugas akhir ini dilakukan dalam rangka memenuhi salah satu syarat untuk mencapai gelar Ahli Madya Keperawatan pada Politeknik Yakpermas Banyumas. Saya menyadari bahwa, tanpa bantuan dan bimbingan dari berbagai pihak pada penyusunan tugas akhir ini, sangatlah sulit bagi saya untuk menyelesaikan laporan ini. Oleh karena itu, saya mengucapkan terimakasih kepada:

1. Rahaju Ningtyas. S.Kp. M.Kep. selaku Direktur Politeknik "Yakpermas" Banyumas dan selaku pembimbing II saya yang banyak membantu dan memberikan masukan sehingga karya tulis ilmiah ini dapat terselesaikan.

2. Ns. Sudiarto., M.Kep selaku penguji utama yang sudah berkenan untuk meluangkan waktunya untuk menguji seminar karya tulis ini.

3. Ns. Puji Indriyani M.Kep selaku pembimbing I yang dengan penuh kesabaran dan ketekunan memberikan dorongan, perhatian, bimbingan, pengarahan, serta saran dalam pembuatan karya tulis ilmiah ini mulai dari awal sampai akhir.

4. Kedua orang tua saya yang telah memberikan semangat dan dukungan material dan moral.
5. Seluruh staf Politeknik "Yakpermas" Banyumas yang telah membantu administrasi dalam penyusunan karya tulis ilmiah ini.

6. Teman-teman dan sahabat yang selalu memberi semangat dan dukungan dalam menyelesaikan Karya Tulis Ilmiah ini.

Semoga bantuan serta budi baik yeng telah diberikan kepada penulis, mendapat balasan dari Allah SWT. Besar harapan penulis agar Karya Tulis Ilmiah akhir ini dapat bermanfaat.

\section{DAFTAR PUSTAKA}

Alimul A. 2012. Metode Penelitian Keperawatan dan Tehnik Analisa Data.Salemba Medika: Jakarta..

Brunner \&Suddarth. 2016. Buku Ajar Keperawatan Medikal Bedah. Edisi12., Jakarta; EGC

Hesti. 2018. Pengaruh Rom (Range Of Motion) Terhadap Kekuatan Otot Ekstremitas Pada Pasien Stroke Non Hemoragic. (Jurnal Ilmiah Penelitian Kesehatan. Vol. 3, No. 2, Desember 2018. Hal. 64-72

Marlina. 2017. Pengaruh Latihan ROM terhadap peningkatan kekuatan otot pada pasien stroke iskemik. Idea Nursing Journal. 3(1): 11-20

Irfan, M. 2010. Fisiologi Bagi Insan Stroke. Edisi Pertama. Yogyakarta: Penerbit GrahaI lmu.

Wayan, 2012.Pengaruh Latihan Range Of Motion (ROM) Pasif Terhadap Peningkatan Kekuatan Otot Ekstremitas Atas Pada pasien Stroke Non Hemoragik. 